\title{
AVALIAÇÃO DEMOCRÁTICA PARA UMA UNIVERSIDADE CIDADÃ
}

\section{Maria de Fátima Arruda Souza}

O livro organizado por Dias Sobrinho e Ristoff discute políticas no campo da avaliação institucional da educação superior. Os sete capítulos foram escritos por diversos autores abordando os seguintes temas:

1) O Exame Nacional de Curso e a Avaliação Institucional, escrito por Ristoff;

2) Educação e Avaliação: técnica e ética, escrito por Dias Sobrinho;

3) Ensino Superior e Formação: elementos para um olhar ampliado de avaliação, de autoria de Goergen;

4) A Política de Avaliação da Educação Superior no Brasil em Questão, escrito por Catani, Oliveira e Dourado;

5) Modelos de Avaliação da Qualidade da Educação Superior, de autoria de Conterá;

6) Avaliação como construção social: reflexões sobre as políticas de avaliação da educação no Brasil, escrito por Meneghel e Lamar; e

7) A avaliação da educação superior no contexto das Políticas Educacionais, de autoria de Almeida Júnior.

Já no primeiro capítulo, Ristoff afirma que a universidade é uma instituição acadêmica e um espaço político, social e cultural, que como tal é cenário de tensão, de conflitos de agentes, de agências, de métodos e técnicas, de propósitos, de ações, de forças representativas de grupos de interesses.

Partindo dessa premissa, o autor acrescenta que conceber a universidade unicamente como espaço burocrático, político ou científico acadêmico equivale a distorcer a sua função e poderá, nos processos avaliativos, exigir dela procedimentos e resultados incompatíveis com sua natureza.

Ristoff declara querer uma educação que oportunize o desenvolvimento da tolerância às diferenças e intolerante com a injustiça, com a miséria, com a falta de respeito pelo outro e com a falta de zelo pela vida; que desen-

* Administradora e Mestre em Educação pela PUCPR. 
volva no aluno a percepção de pertencer a um contexto social específico e promova a compreensão das instituições que organizam a sociedade civilizada. Sendo assim, o autor afirma que a educação cidadã e a educação profissional devem e podem ser vistas como complementares e não como antagônicas.

Ao declarar que o Brasil fez sua opção de abandonar o conceito de modelo único de educação superior, o autor defende que este modelo não se sustenta por estar excessivamente centrado nos interesses da própria academia, esquecendo-se que há sempre na educação muitos interesses em jogo, que precisam ser considerados.

Segundo o autor, uma universidade não pode ser avaliada apenas pela função ensino, nem por mensurações de estilo empresarial, e conclui que um programa de avaliação institucional de natureza formativa e centrado em princípios próximos ao que estabeleceu o PAIUB e que respeite a identidade universitária parece ser a solução.

Dias Sobrinho, no segundo capítulo, alerta que não podemos compreender a avaliação simplesmente como instrumento ou mecanismo técnico, pois apresenta uma profunda dimensão pública e por isso é política e ética.

Ao instigar o leitor a responder o que é avaliação, o autor lembra que avaliação é um fenômeno complexo e permanece incompreensível ou até mesmo se torna deturpado se sobre ele lançamos uma visão simplificadora. Acrescenta que não há um modelo único de avaliação, uma só prática, pois avaliação é construção.

Dias Sobrinho lembra que a técnica há de submeter-se à ética, pois que a técnica é indispensável, mas a ética deve ter primazia. Ao salientar que a educação superior não pode eximir-se de desenvolver, juntamente com a técnica, uma nova ética de fundo político, respeitosa do local e aberta ao global, que renove os espíritos e vontades dos atores da comunidade acadêmica, o autor nos remete à conclusão de que a avaliação não pode se reduzir a controlar ou suprimir a autonomia e a liberdade intelectual. Avaliação é sim, um instrumento a elevar a consciência dos problemas, potenciar os significados dos fenômenos e projetar novas possibilidades de construção.

Na visão do autor, a avaliação da educação exige que se combinem vários enfoques, metodologias, instrumentos e estratégias, de modo particular uma adequada intercomunicação entre os métodos quantitativos e qualitativos.

Dias Sobrinho alerta que nenhuma avaliação é destituída de interesses e indiferente, já que uma prática avaliativa é sempre temporal, situada em contextos humanos cheios de representações e valores e se destina a cumprir interesses de determinados destinatánios. Avaliar significa julgamento de valor, que jamais é neutro. Assim, o autor conclui que cobrir a avaliação-medida com o manto da neutralidade, porque técnica e objetiva, é uma estratégia que 
torna ainda mais incisivo o seu poder de controle e regulação abafando 0 social e seus valores sob a idéia da pura objetividade e da tecnicalidade.

No terceiro capítulo, Goergen afirma que a instituição acadêmica vem se dedicando à formação intelectual e moral de jovens, mas lembra que cada momento histórico apresenta desafios que forçaram-na a repensar-se e transformar-se. $\mathrm{O}$ autor alerta ainda que a sociedade atual apresenta transformações que convocam a universidade a redefinir seus rumos e que esta tarefa cabe muito aos professores universitários.

A universidade, na visão de Goergen, além da focalização de suas especialidades, tem que assumir um olhar panorâmico capaz de perceber a sobreposição de fronteiras nos diferentes temas e assuntos. Assim, cabe à universidade, além de formar profissionais competentes, formar cidadãos conscientes, autônomos e com responsabilidade social.

Para Catani, Oliveira e Dourado, a avaliação no Brasil vem ganhando grande destaque como forma de controle e de definição de políticas que estimulem a expansão competitiva do ensino superior. Os autores citam como exemplo o credenciamento periódico das IES e o Provão. O resultado destes processos de avaliação, na visão dos autores, tem sido a publicação de rankings das universidades.

A proposta de Catani, Oliveira e Dourado é de orientar o sistema de avaliação na direção de examinar a maneira como se produzem e reproduzem as injustiças sociais e as iniqüidades do sistema educacional, com a finalidade de modificar tais processos.

O texto de Contera busca elaborar uma idéia de qualidade da educação superior e de sua avaliação. A autora acredita que na base da avaliação está o problema da qualidade e de quais seriam os indicadores mais adequados para a sua valoração.

Assim, a avaliação da qualidade da educação superior é uma questão chave que requer uma aproximação múltipla e complexa, pois, a forma como se conceitue a idéia de "qualidade" condiciona as definições que são adotadas no terreno da educação em geral e da educação superior em particular.

Contera sustenta a idéia de que o programa de avaliação pode responder ou gerar contextos de liberação ou perda da condição de alienação (do trabalho acadêmico) dado seu caráter democrático. Essa emancipação está vinculada com a possibilidade real de incorporação dos coletivos docentes ao processo de desconstrução criativa e de repensar a universidade, definindo e impulsionando projetos docentes facilitadores de uma maior autonomia e profissionalidade.

Ao refletirem sobre a atual política de avaliação da educação no Brasil, Meneghel e Lamar concluem que esta, assim com seus resultados, não têm conseguido contribuir para uma educação voltada às aspirações e demandas de construção de uma sociedade mais justa e igualitária. Assim, resta às 
instituições e educadores, o desafio de elaborar projetos políticopedagógicos ou planos de desenvolvimento institucional nos quais a avaliação concorra de fato para o aperfeiçoamento de toda a comunidade e para a reflexão do papel da educação no desenvolvimento social.

No último capítulo do livro, Almeida Júnior afirma que a avaliação está intimamente ligada à formulação de políticas sociais, em particular, às de educação.

Segundo o autor, em função da primeira crise capitalista dos anos 70, o Estado passou a se eximir da função de financiar, garantir os direitos sociais básicos, como a saúde, previdência, emprego, habitação e educação e assumiu uma nova e contraditória postura, a de avaliador. Esta nova relação Estado-sociedade fundamenta-se nos princípios da autonomia, da avaliação e da qualidade, culminando num discurso aparentemente democrático e edificante que, no entanto, não revela qual forma de democracia e cidadania se refere: igualdade de oportunidades ou igualdade de escolha num mercado altamente competitivo; garantias dos direitos sociais básicos ou garantias de consumo individual. 